\title{
Enterococcus silesiacus sp. nov. and Enterococcus termitis sp. nov.
}

Correspondence

Pavel Švec

mpavel@sci.muni.cz

\author{
Pavel Švec, ${ }^{1}$ Marc Vancanneyt, ${ }^{2}$ Ivo Sedláček, ${ }^{1}$ Sabri M. Naser, ${ }^{2,3}$ \\ Cindy Snauwaert, ${ }^{2}$ Karen Lefebvre, ${ }^{2}$ Bart Hoste $^{2}$ and Jean Swings ${ }^{2,3}$ \\ ${ }^{1}$ Czech Collection of Microorganisms, Faculty of Science, Masaryk University, Tvrdého 14, \\ 60200 Brno, Czech Republic \\ ${ }^{2,3}$ BCCM/LMG Bacteria Collection ${ }^{2}$ and Laboratory of Microbiology ${ }^{3}$, Faculty of Sciences, \\ Ghent University, Ledeganckstraat 35, B-9000 Ghent, Belgium
}

\begin{abstract}
Three enterococci constituted two aberrant branches after numerical analysis of (GTG) $)_{5}-\mathrm{PCR}$ fingerprints: analogous patterns were found for two water isolates, strains $\mathrm{W} 213$ and $\mathrm{W} 442^{\top}$, and a separate position was found for an isolate from the gut of a termite, strain LMG $8895^{\top}$. $16 \mathrm{~S}$ rRNA gene sequence analysis classified all three strains in the Enterococcus faecalis species group. Further sequencing analysis of the housekeeping gene pheS (encoding the phenylalanyl-tRNA synthase $\alpha$-subunit) and whole-cell-protein analysis confirmed a distinct position for the two water isolates and the termite strain, respectively. DNA-DNA hybridization experiments and distinct phenotypic features between the strains studied and representatives of the $E$. faecalis species group confirmed novel species status, respectively, for the two water isolates, strains W213 and $\mathrm{W} 442^{\top}$, and for strain LMG $8895^{\top}$. The names Enterococcus silesiacus sp. nov. and Enterococcus termitis sp. nov. are proposed for the novel taxa, with W442 ${ }^{\top}\left(=\right.$ CCM $7319^{\top}=$ LMG $\left.23085^{\top}\right)$ and LMG $8895^{\top}\left(=\right.$ CCM $\left.7300^{\top}\right)$ as the respective type strains.
\end{abstract}

Enterococci generally occur as inhabitants of the human and animal intestinal tract, but they are also common in fermented food and are isolated from the environment (Devriese \& Pot, 1995). Although enterococci are considered beneficial and safe members of the population of various fermented products (Giraffa, 2002), they are involved in a variety of human nosocomial infections (Teixeira \& Facklam, 2003). The genus is phylogenetically subdivided into a number of species groups. Within these species groups, enterococcal species share certain physiological and phenotypical characteristics that may be useful for their identification (Devriese et al., 1993). Although this identification approach is still valuable for the most common species, for some of the more recently described species a combination of phenotypic and molecular methods is required for reliable identification (Domig et al., 2003; Devriese et al., 2002). In the present paper, we describe two novel enterococcal species by using a polyphasic approach.

\footnotetext{
Published online ahead of print on 4 November 2005 as DOI 10.1099/ ijs.0.63937-0.

The GenBank/EMBL/DDBJ accession numbers for the 16S rRNA gene sequences of Enterococcus termitis LMG 8895 ${ }^{\top}$, E. silesiacus W442 ${ }^{\top}$ and W213 are AM039968, AM039966 and AM039967, respectively.

A neighbour-joining tree based on the pheS gene sequences and protein profiles of strains $\mathrm{W} 213, \mathrm{~W} 442^{\top}$ and LMG $8895^{\top}$ are available as supplementary material in IJSEM Online.
}

Strains W213 ( = CCM 7318 $=$ LMG 23084) and $\mathrm{W} 442^{\mathrm{T}}$ $\left(=\mathrm{CCM} 7319^{\mathrm{T}}=\mathrm{LMG} 23085^{\mathrm{T}}\right)$ were isolated from drinking water in the region of Silesia in the Czech Republic during a routine microbiological water analysis performed by filtration of a $10 \mathrm{ml}$ water sample through Millipore filters (max. pore size $0 \cdot 45 \mu \mathrm{m}$ ) and cultivation of the filters on SlanetzBartley agar plates for $24 \mathrm{~h}$ at $37^{\circ} \mathrm{C}$ as described by Švec \& Sedláček (1999). Strain LMG $8895^{\mathrm{T}}\left(=\mathrm{CCM} 7300^{\mathrm{T}}\right)$ was isolated from the gut of a termite and was originally described as Lactococcus lactis subsp. lactis. SDS-PAGE of proteins, however, already revealed (results not shown) that the strain was a member of the enterococci. All other type and reference strains included in this study were obtained from the BCCM/LMG Bacteria Collection (http://www. belspo.be/bccm/).

Genotypic characterization was performed using rep-PCR fingerprinting with the (GTG) $)_{5}$ primer as described by Švec et al. (2005). (GTG) $)_{5}$-PCR fingerprints obtained were normalized using BioNumerics (version 4.0) and compared with available profiles in an in-house database (BCCM/ LMG Bacteria Collection) covering all described enterococcal species. Strains W213 and W442 ${ }^{\mathrm{T}}$ showed analogous patterns, and strain LMG $8895^{\mathrm{T}}$ occupied a separate branch distinct from all other reference strains (Fig. 1).

Analysis of the complete 16S rRNA gene sequence of strains W213, W $442^{\mathrm{T}}$ and LMG $8895^{\mathrm{T}}$ was performed as described 


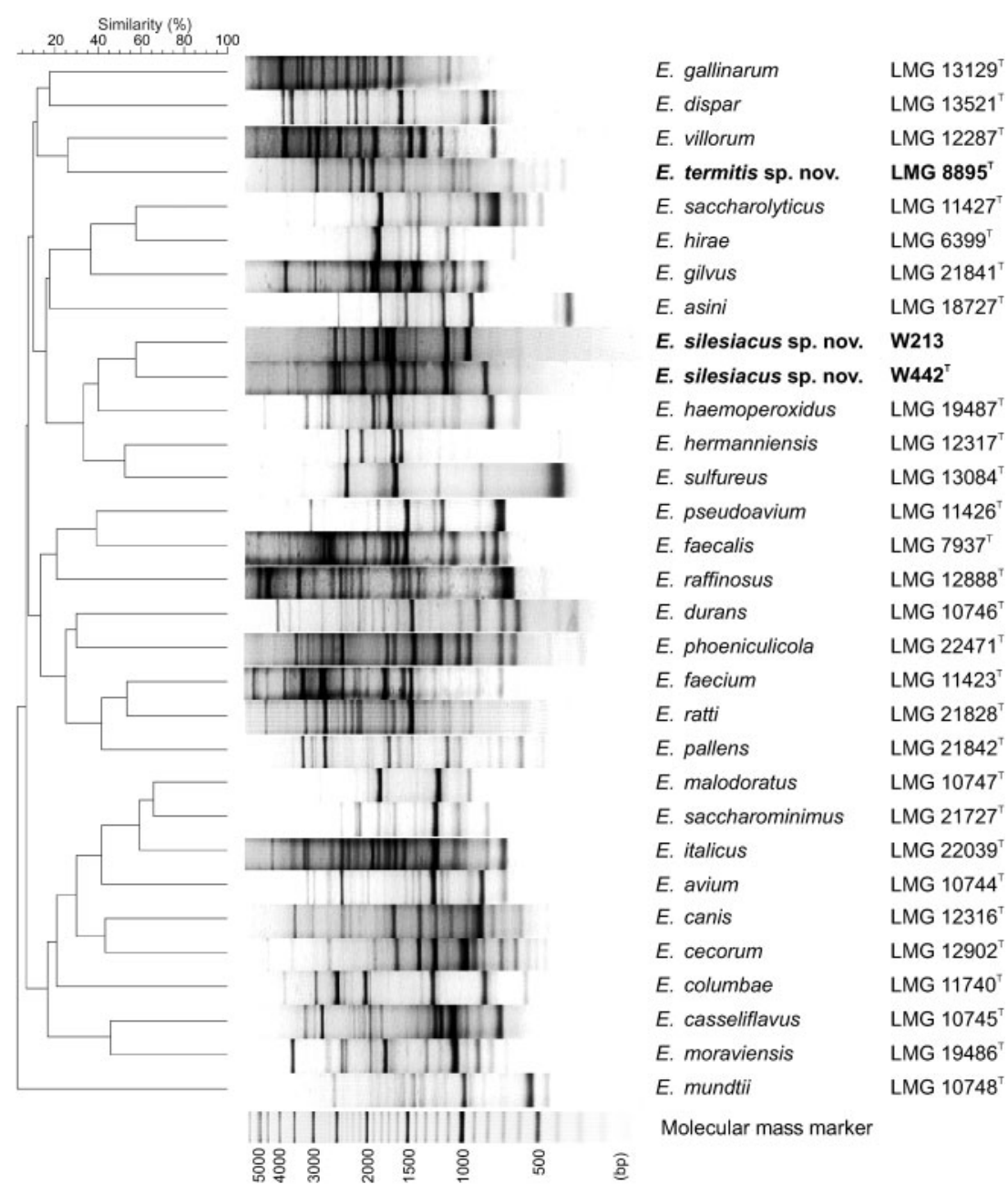

Fig. 1. (GTG $)_{5}-P C R$ fingerprints obtained from strains $\mathrm{W} 213, \mathrm{~W} 442^{\top}$ and LMG $8895^{\top}$ and from the type strains representing all recognized enterococcal species. The dendrogram was calculated with Pearson's correlation coefficient using UPGMA clustering method $(r$, expressed for convenience as percentage similarity values). by Vancanneyt et al. (2004). The sequences obtained and reference sequences (downloaded from the GenBank database) were aligned by using the BioEdit software (Hall, 1999). Evolutionary distances were calculated using the Jukes-Cantor evolutionary model (Jukes \& Cantor, 1969) and a phylogenetic tree was constructed using the neighbourjoining method with the TREECON software (Van De Peer \& De Wachter, 1994). The tree topology obtained with the neighbour-joining method was evaluated and confirmed by the maximum-parsimony analysis using BioNumerics (version 4.0). The phylogenetic analysis placed the three strains in the Enterococcus faecalis species group (Fig. 2), which accommodates E. faecalis, Enterococcus haemoperoxidus and Enterococcus moraviensis (Švec et al., 2001). Strains W213 and $\mathrm{W}_{442}{ }^{\mathrm{T}}$ showed $99 \cdot 9 \%$ 16S rRNA gene sequence similarity to each other and showed E. haemoperoxidus and E. moraviensis as their closest phylogenetic relatives with similarities ranging from $99 \cdot 0$ to $99 \cdot 2 \%$. Similarly, strain LMG $8895^{\mathrm{T}}$ showed $98.9 \% 16 \mathrm{~S}$ rRNA gene sequence similarity with E. haemoperoxidus and $98 \cdot 8 \%$ with E. moraviensis species. Sequence similarity between strain LMG $8895^{\mathrm{T}}$ and strains $\mathrm{W} 213$ and $\mathrm{W} 442^{\mathrm{T}}$ was $99 \cdot 3 \%$.
Amplification and partial sequencing of the pheS gene (encodes a phenylalanyl-tRNA synthase) were performed by using pheS primers: pheS-21-F (5'-CAYCCNGCHCGYGAYATGC-3'), pheS-22-R (5'-CCWARVCCRAARGCAAARCC- $\left.3^{\prime}\right)$ and pheS-23-R (5'-GGRTGRACCATVCCNGCHCC- $3^{\prime}$ ), which enabled the comparison of a 455 bp gene fragment. The pheS primers were designed based on a selection of the most conservative regions of the pheS gene sequence of representative lactic acid bacteria obtained from publicly available data of whole-genome-sequence projects. Sequencing primer designs, amplification conditions and sequencing parameters were performed as described by Naser et al. (2005). Although the sequences obtained represent only about half of the gene, Naser et al. (2005) demonstrated that this region shows sufficient diversity to distinguish individual species. Different enterococcal species have a maximum of $86 \%$ pheS gene sequence similarity and the intraspecies variation showed a high degree of homogeneity of at least $97 \%$ among strains of the same species. This suggested that pheS is a fast-evolving clock and a valuable tool for identification of enterococci; however, the topology obtained in the pheS dendrogram does not reflect 


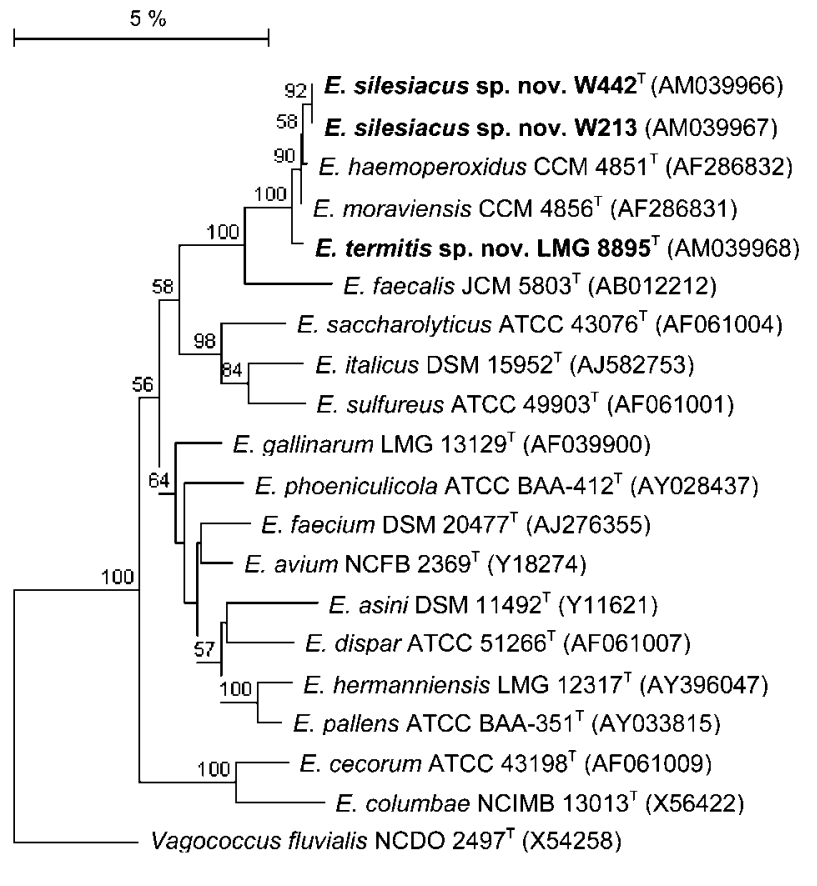

Fig. 2. Distance-matrix tree based on 16S RNA gene sequence comparisons showing the phylogenetic relationships of strains W213, W442 ${ }^{\top}$ and LMG $8895^{\top}$ and selected enterococcal species representing phylogenetic neighbours and intraspecies lineages. The Vagococcus fluvialis (X54258) sequence was used as the outgroup. Bootstrap percentage values (500 tree replications) higher than $50 \%$ are indicated at branch points. GenBank accession numbers are stated in parentheses. Bar, $5 \%$ evolutionary distance.

the phylogenetic relationships revealed by $16 \mathrm{~S}$ rRNA gene sequencing (Naser et al., 2005). The pheS gene sequence analysis indicated that the two water isolates (W213 and $\mathrm{W} 442^{\mathrm{T}}$ ) are members of a single species $(99 \cdot 3 \%$ sequence similarity to each other). Comparison with reference strains revealed the highest sequence similarity of $86 \cdot 8 \%$ with $E$. moraviensis for both strains. Strain LMG $8895^{\mathrm{T}}$ was differentiated from the above-mentioned isolates (sequence similarity of $84 \cdot 0 \%$ ) and from all enterococcal type strains included in the database and constituted a single separate branch with the highest sequence similarity of $82 \cdot 6 \%$ with $E$. moraviensis as shown in Supplementary Fig. S1 (available in IJSEM Online). The latter data are an indication that both taxa might represent novel species.

Whole-cell-protein analysis was performed with cells grown on MRS agar (Oxoid) for $24 \mathrm{~h}$ at $37^{\circ} \mathrm{C}$. Protein extraction, electrophoresis, SDS-PAGE, densitometric analysis and further analysis of the profiles were performed following the procedure described by Pot et al. (1994). Protein profiles were compared to an in-house database (BCCM/LMG Bacteria Collection) comprising multiple representative strains of all described enterococcal species. The similarity between all pairs of traces was expressed by Pearson's product-moment correlation coefficient. UPGMA (unweighted pair group method using arithmetic averages) clustering was used for the construction of the dendrogram. Supplementary Fig. S2 (available in IJSEM Online) shows the whole-cell-protein profiles obtained from investigated strains as well as from their nearest phylogenetic neighbours E. faecalis, E. haemoperoxidus and E. moraviensis. The three new isolates were highly similar to E. haemoperoxidus and E. moraviensis reference strains. Still, the water isolates (strains W213 and $\mathrm{W} 442^{\mathrm{T}}$ ) constituted a single cluster and showed minor differences from strain LMG $8895^{\mathrm{T}}, E$. haemoperoxidus and E. moraviensis.

The DNA base composition was determined for strains W213, W442 ${ }^{\mathrm{T}}$ and LMG $8895^{\mathrm{T}}$. Isolation of high-molecularmass DNA from bacterial cells grown in Todd-Hewitt broth (Oxoid), degradation of the DNAs into nucleosides and their separation by HPLC were carried out as described by Vancanneyt et al. (2004). The DNA G+C content of strains W213, W442 ${ }^{\mathrm{T}}$ and LMG $8895^{\mathrm{T}}$ were $35 \cdot 6,36 \cdot 7$ and $37 \cdot 1 \mathrm{~mol} \%$, respectively. These results correspond to the DNA $G+C$ content of the E. faecalis species group that range from $34 \cdot 3$ to $37 \cdot 7 \mathrm{~mol} \%$ (Švec et al., 2001).

DNA-DNA hybridization experiments were performed between strains W213, W442 ${ }^{\mathrm{T}}$ and LMG $8895^{\mathrm{T}}$ and $E$. faecalis LMG $7937^{\mathrm{T}}$, E. moraviensis LMG $19486^{\mathrm{T}}$ and $E$. haemoperoxidus LMG $19487^{\mathrm{T}}$. High-molecular-mass DNA was isolated as described for determination of the DNA base composition and DNA-DNA hybridization experiments were performed in microdilution wells according to Vancanneyt et al. (2004). The hybridization temperature was $32^{\circ} \mathrm{C}$ (calculated as described by Švec et al., 2001). A high DNA-binding value of $93 \%$ was found between strains $\mathrm{W} 213$ and $\mathrm{W} 442^{\mathrm{T}}$ and confirms that they represent a single species. DNA-DNA-binding levels between strains W213 and $\mathrm{W} 442^{\mathrm{T}}$ and E. faecalis LMG $7937^{\mathrm{T}}$, E. moraviensis LMG $19486^{\mathrm{T}}$ and E. haemoperoxidus LMG $19487^{\mathrm{T}}$ were 12 and $13 \%, 41$ and $43 \%$ and 48 and $46 \%$, respectively. Binding levels between strain LMG $8895^{\mathrm{T}}$ and E. faecalis LMG $7937^{\mathrm{T}}$, E. moraviensis LMG $19486^{\mathrm{T}}$ and E. haemoperoxidus LMG $19487^{\mathrm{T}}$ were 12,26 and $30 \%$, respectively. The water isolates $\mathrm{W} 213$ and $\mathrm{W} 442^{\mathrm{T}}$ and strain LMG $8895^{\mathrm{T}}$ showed binding levels between 25 and $26 \%$. These data confirm that the water isolates W213 and W442 ${ }^{\mathrm{T}}$ and strain LMG $8895^{\mathrm{T}}$ represent two novel enterococcal species.

Growth and biochemical tests were carried out by using API 20 Strep and API 50CH commercial kits (bioMérieux) as well as by conventional tests described by Švec et al. (2001). Results are given in the species descriptions below. The species can be differentiated from their phylogenetically closest known relatives by using the tests listed in Table 1.

All results obtained in this study confirmed the analysed strains as members of two novel enterococcal species, for which the names Enterococcus silesiacus sp. nov. and Enterococcus termitis sp. nov. are proposed. 
Table 1. Biochemical tests useful for differentiation of Enterococcus silesiacus sp. nov., E. termitis sp. nov. and their phylogenetic relatives assigned in the $E$. faecalis species group

Taxa: 1, E. silesiacus sp. nov.; 2, E. termitis sp. nov.; 3, E. faecalis; 4, E. haemoperoxidus; 5, E. moraviensis. Characteristics scored as: +, positive; -, negative; d, variable. Data described by Švec et al. (2001), de Vaux et al. (1998), Schleifer \& Kilpper-Bälz (1984) and Devriese et al. (1983) or obtained in this study.

\begin{tabular}{|lccccc|}
\hline Characteristic & $\mathbf{1}$ & $\mathbf{2}$ & $\mathbf{3}$ & $\mathbf{4}$ & $\mathbf{5}$ \\
\hline Arginine dihydrolase & + & - & + & + & - \\
Acetoin (VP test) & + & - & + & + & + \\
$\beta$-Galactosidase & + & - & - & - & $\mathrm{d}$ \\
Hippurate hydrolysis & - & - & + & + & + \\
Acid production from: & & & & & \\
$\quad$ Melezitose & - & - & $\mathrm{d}$ & + & + \\
L-Arabinose & $\mathrm{d}$ & - & - & - & + \\
Gluconate & $\mathrm{d}$ & + & $\mathrm{d}$ & - & - \\
Methyl $\alpha$-D-glucopyranoside & - & + & - & + & + \\
Methyl $\alpha$-D-mannopyranoside & - & + & - & - & - \\
Sucrose & - & - & + & + & + \\
D-Tagatose & - & - & + & - & + \\
D-Xylose & + & + & - & - & - \\
\hline
\end{tabular}

\section{Description of Enterococcus silesiacus sp. nov.}

Enterococcus silesiacus (si.le' si.a.cus. N.L. masc. adj. silesiacus pertaining to Silesia, the region in the Czech Republic from which the type strain originates).

Cells are Gram-positive, ovoid cocci, occurring in pairs, short chains or small groups. They elongate in the direction of the chains. Colonies on Columbia agar supplemented with sheep blood are non-pigmented, shiny, circular, smooth with entire margins and about $1 \mathrm{~mm}$ in diameter after $24 \mathrm{~h}$ of cultivation at $37^{\circ} \mathrm{C}$. The type strain of the species grows well on Todd-Hewitt agar and brain heart infusion (BHI) agar; growth on MRS medium is less abundant. Poor growth on Slanetz-Bartley medium containing $0.04 \%$ sodium azide in small dark-red colonies. Growth with positive aesculin reaction on kanamycin/aesculin/azide agar and bile/aesculin agar. Non-motile. Growth occurs in BHI broth at $10{ }^{\circ} \mathrm{C}$, no growth occurs at $45^{\circ} \mathrm{C}$ and is weak in the presence of $6 \cdot 5 \% \mathrm{NaCl}$ and at $\mathrm{pH} 9 \cdot 6$. Positive catalase reaction when cultivated on blood-containing agar, but catalase-negative on blood-free medium. Produces arginine dihydrolase, pyrrolidonyl arylamidase, leucine aminopeptidase, acetoin (Voges-Proskauer test) and $\beta$-galactosidase. Does not produce alkaline phosphatase, $\alpha$-galactosidase and $\beta$-glucuronidase. Hippurate hydrolysis is negative; aesculin hydrolysis is positive. Acid is produced from glycerol, D-ribose, D-xylose, D-galactose, D-glucose, D-fructose, Dmannose, $N$-acetylglucosamine, amygdalin, arbutin, salicin, $\mathrm{D}$-cellobiose, $\mathrm{D}$-maltose, $\mathrm{D}$-lactose, $\mathrm{D}$-trehalose and gentiobiose. Acid is not produced from erythritol, D-arabinose,
L-xylose, D-adonitol, methyl $\beta$-D-xylopyranoside, L-sorbose, L-rhamnose, dulcitol, inositol, D-mannitol, D-sorbitol, methyl $\alpha$-D-mannopyranoside, methyl $\alpha$-D-glucopyranoside, D-melibiose, sucrose, inulin, D-melezitose, D-raffinose, starch, glycogen, xylitol, D-turanose, D-lyxose, D-tagatose, D-fucose, L-fucose, D-arabitol, L-arabitol, 2-ketogluconate or 5-ketogluconate. Acid production from L-arabinose (strain W213 is weakly positive in API $50 \mathrm{CH}$ kit, but negative using API 20 Strep; strain $\mathrm{W} 442^{\mathrm{T}}$ is negative) and gluconate (strain $\mathrm{W} 213$ is positive, $\mathrm{W} 442^{\mathrm{T}}$ is negative) is variable. The $\mathrm{G}+\mathrm{C}$ content of strains $\mathrm{W} 213$ and $\mathrm{W} 442^{\mathrm{T}}$ is $35 \cdot 6$ and $36 \cdot 7 \mathrm{~mol} \%$, respectively.

The type strain, $\mathrm{W} 442^{\mathrm{T}}\left(=\mathrm{CCM} 7319^{\mathrm{T}}=\mathrm{LMG} 23085^{\mathrm{T}}\right)$, and the other strain, W213 (=CCM 7318=LMG 23084), were isolated from surface waters.

\section{Description of Enterococcus termitis sp. nov.}

Enterococcus termitis (ter.mi' tis. L. n. termes -itis a worm that eats wood, a woodworm, and in zoology the name of a scientific genus; L. gen. n. termitis of a termite).

Cells are Gram-positive, ovoid cocci, occurring in pairs, short chains or small groups. They elongate in the direction of the chains. Colonies on Columbia agar supplemented with sheep blood are non-pigmented, shiny, circular, smooth with entire margins and about $1 \mathrm{~mm}$ in diameter after $24 \mathrm{~h}$ of cultivation at $37^{\circ} \mathrm{C}$. The type strain of the species grows well on Todd-Hewitt agar and BHI agar; growth on MRS medium is less abundant. Poor growth on Slanetz-Bartley medium containing 0.04\% sodium azide in small dark-red colonies. Positive growth with positive aesculin reaction on kanamycin/aesculin/azide agar and bile/aesculin agar. Non-motile. Growth occurs in BHI broth at $10-45^{\circ} \mathrm{C}, \mathrm{pH} 9.6$ and in the presence of $6.5 \% \mathrm{NaCl}$. Catalase reaction is negative on blood-containing as well as on blood-free media. Produces leucine aminopeptidase. Does not produce pyrrolidonyl arylamidase, arginine dihydrolase, acetoin (Voges-Proskauer test), $\alpha$-galactosidase, $\beta$-galactosidase, $\beta$-glucuronidase or alkaline phosphatase. Hippurate hydrolysis is negative; aesculin hydrolysis is positive. Acid is produced from glycerol, ribose, D-xylose, D-galactose, D-glucose, D-fructose, D-mannose, methyl $\alpha$-Dmannopyranoside, methyl $\alpha$-D-glucopyranoside, $N$-acetylglucosamine, amygdalin, arbutin, salicin, D-cellobiose, Dmaltose, D-lactose, D-trehalose, gentiobiose and gluconate. Acid is not produced from erythritol, D-arabinose, Larabinose, $\mathrm{L}$-xylose, $\mathrm{D}$-adonitol, methyl $\beta$-D-xylopyranoside, L-sorbose, L-rhamnose, dulcitol, inositol, D-mannitol, Dsorbitol, D-melibiose, sucrose, inulin, D-melezitose, Draffinose, starch, glycogen, xylitol, D-turanose, D-lyxose, D-tagatose, D-fucose, L-fucose, D-arabitol, L-arabitol, 2ketogluconate or 5-ketogluconate. The $\mathrm{G}+\mathrm{C}$ content of the type strain is $37 \cdot 1 \mathrm{~mol} \%$.

The type strain, LMG $8895^{\mathrm{T}}\left(=\mathrm{CCM} 7300^{\mathrm{T}}\right)$, originated from the gut of a termite. 


\section{Acknowledgements}

P. S. and J.S. thank the Belgian Federal Science Policy Office for a research fellowship in the framework of the promotion of S\&T cooperation with Central and Eastern Europe. S. M. N. acknowledges a PhD scholarship from the Palestinian Ministry of Education and Higher Education. This work was supported in part by the Ministry of Education of the Czech Republic (MSM0021622416).

\section{References}

de Vaux, A., Laguerre, G., Divies, C. \& Prevost, H. (1998). Enterococcus asini sp. nov. isolated from the caecum of donkeys (Equus asinus). Int J Syst Bacteriol 48, 383-387.

Devriese, L. A. \& Pot, B. (1995). The genus Enterococcus. In The Genera of Lactic Acid Bacteria, pp. 327-367. Edited by B. J. B. Wood \& W. H. Holzapfel. London: Blackie Academic \& Professional.

Devriese, L. A., Dutta, G. N., Farrow, J. A. E., van der Kerckhove, A. \& Phillips, B. A. (1983). Streptococcus cecorum, a new species isolated from chickens. Int J Syst Bacteriol 33, 772-776.

Devriese, L. A., Pot, B. \& Collins, M. D. (1993). Phenotypic identification of the genus Enterococcus and differentiation of phylogenetically distinct enterococcal species and species groups. J Appl Bacteriol 75, 399-408.

Devriese, L. A., Vancanneyt, M., Descheemaeker, P., Baele, M., Van Landuyt, H. W., Gordts, B., Butaye, P., Swings, J. \& Haesebrouck, F. (2002). Differentiation and identification of Enterococcus durans, E. hirae and E. villorum. J Appl Microbiol 92, 821-827.

Domig, K. J., Mayer, H. K. \& Kneifel, W. (2003). Methods used for the isolation, enumeration, characterisation and identification of Enterococcus spp. 2. Pheno- and genotypic criteria. Int J Food Microbiol 88, 165-188.

Giraffa, G. (2002). Enterococci from foods. FEMS Microbiol Rev 26, 163-171.

Hall, T. A. (1999). BioEdit: a user-friendly biological sequence alignment editor and analysis program for Windows 95/98/NT. Nucleic Acids Symp Ser 41, 95-98.
Jukes, T. H. \& Cantor, C. R. (1969). Evolution of protein molecules. In Mammalian Protein Metabolism, vol. 3, pp. 21-132. Edited by H. N. Munro. New York: Academic Press.

Naser, S. M., Thompson, F. L., Hoste, B., Gevers, D., Dawyndt, P., Vancanneyt, M. \& Swings, J. (2005). Application of multilocus sequence analysis (MLSA) for rapid identification of Enterococcus species based on rpoA and pheS genes. Microbiology 151, 2141-2150.

Pot, B., Vandamme, P. \& Kersters, K. (1994). Analysis of electrophoretic whole-organism protein fingerprints. In Modern Microbial Methods. Chemical Methods in Prokaryotic Systematics, pp. 493-521. Edited by M. Goodfellow \& A. G. O'Donnell. Chichester, UK: Wiley.

Schleifer, K. H. \& Kilpper-Bälz, R. (1984). Transfer of Streptococcus faecalis and Streptococcus faecium to the genus Enterococcus nom. rev. as Enterococcus faecalis comb. nov. and Enterococcus faecium comb. nov. Int J Syst Bacteriol 34, 31-34.

Švec, P. \& Sedláček, I. (1999). Occurrence of Enterococcus spp. in waters. Folia Microbiol 44, 3-10.

Švec, P., Devriese, L. A., Sedláček, I., Baele, M., Vancanneyt, M., Haesebrouck, F., Swings, J. \& Doškař, J. (2001). Enterococcus haemoperoxidus sp. nov. and Enterococcus moraviensis sp. nov., isolated from water. Int J Syst Evol Microbiol 51, 1567-1574.

Švec, P., Vancanneyt, M., Seman, M., Snauwaert, C., Lefebvre, K., Sedláček, I. \& Swings, J. (2005). Evaluation of (GTG) $)_{5}-\mathrm{PCR}$ for identification of Enterococcus spp. FEMS Microbiol Lett 247, 59-63.

Teixeira, L. M. \& Facklam, R. R. (2003). Enterococcus. In Manual of Clinical Microbiology, 8th edn, pp. 422-433. Edited by P. R. Murray, E. J. Baron, J. H. Jorgensen, M. A. Pfaller \& R. H. Yolken. Washington, DC: American Society for Microbiology.

Vancanneyt, M., Zamfir, M., Devriese, L. A. \& 7 other authors (2004). Enterococcus saccharominimus sp. nov., from dairy products. Int J Syst Evol Microbiol 54, 2175-2179.

Van de Peer, Y. \& De Wachter, R. (1994). TREECON for Windows: a software package for the construction and drawing of evolutionary trees for the Microsoft Windows environment. Comput Appl Biosci 10, 569-570. 